\title{
Analisis Saluran Pemasaran dan Marjin Pemasaran Bahan Olahan Karet Rakyat (Bokar) di Kabupaten Kampar
}

\author{
Shorea Khaswarina*, Yeni Kusumawaty, Eliza \\ Jurusan Agribisnis, Fakultas Pertanian, Universitas Riau \\ * shoreakhaswarina@gmail.com
}

\begin{abstract}
Abstrak. Penelitian ini bertujuan untuk mengetahui saluran pemasaran yang paling efisien yang digunakan oleh petani karet di lokasi penelitian dan untuk mengetahui besarnya nilai keuntungan masing-masing lembaga pemasaran pada setiap saluran pemasaran. Metode penelitian untuk melihat efisiensi pemasaran digunakan analisis margin pemasaran, farmer's share, dan Profitability Index. Penentuan responden dilakukan secara purposive sampling dengan jumlah responden sebanyak 84 orang, yaitu petani karet 75 orang dan pedagang perantara 9 orang. Hasil penelitian menunjukkan bahwa saluran pemasaran paling efisien berdasarkan nilai marjin pemasaran, farmer's share dan tingkat keuntungan (profitability index) yang diperoleh terdapat pada saluran pemasaran III di Desa Ridan, dengan nilai keuntungan pemasaran sebesar Rp. 1.037,5 margin pemasaran sebesar Rp.1.905 dan nilai farmer's share sebesar $77,91 \%$ dengan efisiensi pemasaran $20,19 \%$.
\end{abstract}

Kata Kunci: efisiensi, saluran pemasaran, bokar

\section{PENDAHULUAN}

Pemasaran merupakan aspek yang sangat penting dalam sistem agribisnis. Jika mekanisme pemasaran berjalan baik, maka semua pihak yang terlibat akan diuntungkan. Oleh karena itu peran lembaga pemasaran menjadi sangat penting. Proses pemasaran harus berlangsung efisien, untuk mengukur prestasi kerja dari proses pemasaran digunakan efisiensi pemasaran. Faktor-faktor yang dapat sebagai ukuran efisiensi pemasaran diantaranya adalah keuntungan pemasaran, harga yang diterima konsumen, tersedianya fasilitas fisik pemasaran yang memadai untuk melancarkan transaksi jual beli barang, penyimpanan, transportasi, dan kompetisi pasar, persaingan diantara pelaku pemasaran (Soekartawi, 1993).

Kabupaten Kampar merupakan salah satu sentra produksi karet di Provinsi Riau, sehingga perkebunan karet salah satu sumber mata pencarian utama masyarakat. Kondisi ini didukung dengan Data dari BPS Kabupaten Kampar (2017) yaitu jumlah petani karet rakyat di Kabupaten Kampar sebanyak 52.117 Kepala Keluarga. Namun sampai saat ini, masalah utama di perkebunan karet rakyat yang belum mampu diatasi diantaranya adalah sistem pemasaran bokar yang belum efisien. Oleh karena itu, kajian ini sangat penting karena melalui sistem pemasaran yang dilakukan dapat ditentukan tingkat keuntungan yang diperoleh oleh petani. Besar kecil keuntungan yang diperoleh oleh petani tergantung proses pemasaran yang dilakukan. Semakin efisien pemasaran, maka akan semakin besar keuntungan yang dapat diperoleh. Namun adanya lembaga pemasaran menyebabkan membesarnya biaya- biaya pemasaran. Biaya pemasaran tersebut kemudian diperhitungkan pada penentuan harga yang diberikan pedagang pengumpul kepada produsen. Produsen adalah petani karet, pelaku pemasaran yang paling dirugikan dalam hal ini, karena memperoleh harga yang paling rendah daripada pelaku pemasaran lainnya. Kondisi ini sangat mempengaruhi keberlanjutan perkebunan karet di Kabupaten Kampar. Untuk mengatasi permasalahan tersebut, maka perlu dilakukan kajian analisis saluran pemasaran dan marjin pemasaran bahan olahan karet rakyat (bokar) di kabupaten Kampar. Kajian ini dilakukan untuk memperoleh informasi penting yang berguna untuk keberlanjutan usahatani karet di Kabupaten Kampar Provinsi Riau. 


\section{KAJIAN PUSTAKA}

Pemasaran merupakan aspek yang sangat penting dalam sistem agribisnis. Jika mekanisme pemasaran berjalan baik, maka semua pihak yang terlibat akan diuntungkan. Oleh karena itu peran lembaga pemasaran yang biasanya terdiri dari produsen, tengkulak, pedagang pengumpul, broker, eksportir, importir dan yang lainnya menjadi amat penting. Biasanya pada Negara berkembang, lembaga pemasaran untuk pemasaran hasil pertanian masih lemah (Soekartawi, 2002). Pemasaran merupakan suatu disiplin ilmu yang dipergunakan oleh perusahaan untuk memenuhi kebutuhan konsumen menjadi peluang yang menghasilkan laba perusahaan. Definisi pemasaran menurut Kotler (2009), adalah proses sosial yang didalamnya individu dan kelompok mendapatkan apa yang mereka butuhkan dan inginkan dengan menciptakan, menawarkan dan secara bebas mempertukarkan produk yang bernilai dengan pihak lain. Pemasaran merupakan kegiatan inti dari tiap perusahaan sehingga perlu adanya pengelolaan dan koordinasi secara baik dan profesional.

Proses pemasaran harus berlangsung efisien, untuk mengukur prestasi kerja dari proses pemasaran digunakan efisiensi pemasaran. Teknologi atau prosedur baru hanya boleh diterapkan bila dapat meningkatkan efisiensi proses pemasaran (Downey dan Erickson, 1989). Untuk mendapatkan pemasaran yang lebih efisien menurut Mubyarto (1985) ada dua persyaratan yang harus dipenuhi yaitu: (a) mampu menyampaikan hasil-hasil dari petani produsen kepada konsumen dengan biaya yang semurah-murahnya, dan (b) mampu mengadakan pembagian yang adil dari keseluruhan harga yang dibayar konsumen terakhir kepada semua pihak yang ikut serta didalam kegiatan produksi dan pemasaran barang itu. Faktor-faktor yang dapat sebagai ukuran efisiensi pemasaran adalah sebagai berikut: a). Keuntungan pemasaran (b). Harga yang diterima konsumen (c). Tersedianya fasilitas fisik pemasaran yang memadai untuk malancarkan transaksi jual beli barang, penyimpanan, transportasi, dan (d). Kompetisi pasar, persaingan diantara pelaku pemasaran (Soekartawi, 1993).

Keterlibatan pedagang perantara akan menyebabkan harga yang diterima petani produsen dan yang dibayarkan konsumen jauh berbeda. Hal ini disebabkan adanya fungsi-fungsi yang harus dilakukan oleh pedagang perantara. Fungsi tersebut yaitu fungsi pertukaran (exchange), fungsi penyediaan fisik dan logistic, dan fungsi pemberian fasilitas (facilitating function) sehingga menimbulkan adanya biaya pemasaran. Biaya pemasaran biasanya oleh perantara akan dibebankan kepada produsen. Besarnya biaya pemasaran dan keuntungan yang diterima pedagang perantara merupakan margin pemasaran (Gitosudarmo, 2001). Marjin pemasaran adalah perbedaan harga yang diterima produsen terhadap harga pokok yang dibayarkan oleh konsumen akhir (Azzaino, 1991).

\section{METODE}

Lokasi penelitian dipilih secara sengaja (purposive), yaitu Desa Sungai Pinang Kecamatan Kampar, Desa Kuapan Kecamatan Tambang dan Desa Ridan Kecamatan Bangkinang Kabupaten Kampar. Lokasi ini dipilih dengan pertimbangan masyarakat petani di desa tersebut mayoritas hanya berusahatani komoditi karet rakyat dan menjadi mata pencaharian tetap sehari-hari juga merupakan salah satu daerah yang jauh dari sentral pemasaran komoditi karet atau pabrik. Waktu penelitian berlangsung selama 6 bulan, yaitu dari tanggal April 2018 sampai Oktober 2018. Populasi dalam penelitian ini adalah seluruh petani karet rakyat yang berjumlah 250 petani dan lembaga-lembaga perantara yang terlibat dalam proses pemasaran karet rakyat di lokasi penelitian. Sehingga penentuan responden dalam penelitian ini menggunakan teknik acak sederhana yang menghasilkan 84 responden yang terdiri dari 75 petani karet, dan 9 orang pedagang

Data dianalisis secara deskriptif yaitu meliputi margin pemasaran, saluran pemasaran, biaya pemasaran, farmer share, keuntungan pemasaran dan efisiensi pemasaran.

Marjin pemasaran adalah perbedaan harga pada tingkat petani sebagai produsen dengan harga pada tingkat konsumen. Pada dasarnya marjin pemasaran adalah penjumlahan dari biaya-biaya pemasaran dan keuntungan lembaga yang memberi jasa dalam proses pemasaran. Secara matematis marjin pemasaran di rumuskan sebagai berikut:

\section{a. Marjin Pemasaran (Maulidi dkk., 1992)}

$$
\mathrm{Mji}=\text { Pri }- \text { Pfi atau Mji }=\text { bi }+ \text { ki }
$$

dimana:

$\mathrm{Mji} \quad=$ Marjin pedagang pengumpul $(\mathrm{Rp} / \mathrm{Kg})$

Pri = Harga ditingkat berikutnya $(\mathrm{Rp} / \mathrm{Kg})$

Pfi = Harga ditingkat Petani $(\mathrm{Rp} / \mathrm{Kg})$ 
$\mathrm{Bi} \quad=$ Biaya pemasaran pada lembaga ke-I $(\mathrm{Rp} / \mathrm{Kg})$

$\mathrm{Ki} \quad=$ Keuntungan lembaga pemasaran pada lembaga ke-I $(\mathrm{Rp} / \mathrm{Kg})$

Bagian harga yang diterima oleh petani sebagai produsen dalam pemasaran komoditas pertanian (Farmer's Share) merupakan perbandingan harga yang diterima petani sebagai produsen dengan harga yang di bayarkan konsumen akhir. Farmer's share berkorelasi negatif dengan marjin pemasaran, artinya semakin tinggi marjin pemasaran maka bagian harga yang diterima petani sebagai produsen semakin rendah sebagaimana dirumuskan berikut ini:

\section{b. Farmer's Share (Azzaino, 1991)}

$$
\mathrm{Fs}=\mathrm{Pf} / \mathrm{Pc} \times 100 \%
$$

dimana:

$$
\begin{array}{ll}
\mathrm{Pf} & =\text { Harga ditingkat petani }(\mathrm{Rp} / \mathrm{Kg}) \\
\mathrm{Pc} & =\text { Harga ditingkat konsumen }(\mathrm{Rp} / \mathrm{Kg}) \\
\mathrm{Fs} & =\text { Bagian yang diterima petani }
\end{array}
$$

Suatu pemasaran dikatakan efisien apabila:

1) Mempunyai margin yang rendah dan Farmer's Share yang tinggi dibandingkan pemasaran yang lain untuk komoditas yang sama ( $\mathrm{FS}>\mathrm{MP}$ ).

2) Mampu mengadakan pembagian yang adil dari keseluruhan harga yang dibayar konsumen terakhir kepada pihak yang ikut serta dalam kegiatan produksi dan pemasaran karet.

Untuk mengetahui besarnya tingkat keuntungan dari semua lembaga pemasaran yang terlibat dengan menggunakan rumus Profitability Index (PI) adalah sebagai berikut:

$$
\mathrm{PI}=\mathrm{KI} / \mathrm{Bi} \text { dan } \mathrm{Ki}=\mathrm{Pji}-\mathrm{Pbi}-\mathrm{Bij}
$$

dimana:

PI = Profitability Index

$\mathrm{Ki} \quad=$ Keuntungan Pemasaran $(1=1,2, . . \mathrm{m} ; \mathrm{m}=$ jumlah lembaga pemasaran yang terlibat $)$

$\mathrm{Bi}=$ Biaya pemasaran $(1=1,2, \ldots \mathrm{z} ; \mathrm{z}=$ jumlah jenis biaya $)$

Pji = Harga jual ke I

$\mathrm{Pbi}=$ Harga beli lembaga ke I

$\mathrm{Bij}=$ Biaya pemasaran lembaga ke I dari berbagai jenis.

Adapun kriteria dari analisis profitability index menurut (Maulidi, Sitorus dan Mahdi, 1992) adalah:

1) Apabila indeks keuntungan dibagi biaya pemasaran $=1$ atau keuntungan dibagi biaya pemasaran $>1$ maka pemasaran dikatakan efisien.

2) Apabila index keuntungan dibagi biaya pemasaran $<1$ maka pemasaran tidak efisien.

\section{HASIL DAN PEMBAHASAN}

Saluran pemasaran dianalisis secara deskriptif, yaitu dengan melihat aliran yang dilalui oleh lembagalembaga pemasaran yang ada dalam proses pemasaran, hasil produksi karet mulai dari petani hingga sampai ke pabrik sebagai konsumen. Petani karet yang ada di Kabupaten Kampar tidak menjual langsung hasil produksi karetnya ke konsumen akhir disebabkan keterbatasan yang dimiliki oleh petani. Keterbatasaan yang dimiliki petani yaitu jumlah produksi yang tidak terlalu banyak dan jauhnya lokasi pabrik dari desa tersebut. Oleh karena itu petani membutuhkan lembaga pemasaran yang menyalurkan hasil produksi sampai ke konsumen akhir.

Panjang pendeknya saluran pemasaran akan berpengaruh pada harga yang akan diterima oleh petani sebagai produsen. Tugas lembaga pemasaran ini adalah menjalankan fungsi-fungsi pemasaran serta memenuhi keinginan konsumen semaksimal mungkin (Sudiyono, 2001). Berikut saluran pemasaran karet yang ada di Kabupaten Kampar.

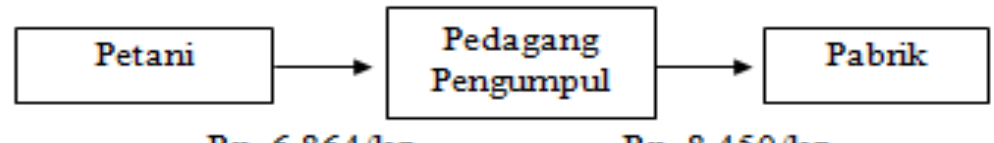

Rp. $6.864 / \mathrm{kg} \quad$ Rp. $8.450 / \mathrm{kg}$

Gambar 1. Saluran Pemasaran di Desa Sungai Pinang 


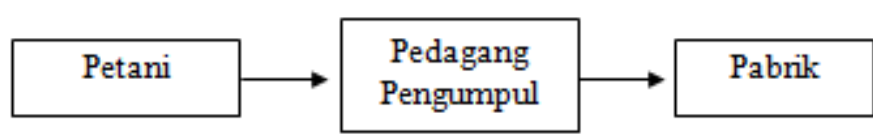

Rp. $6.756 / \mathrm{kg} m \mathrm{Rp}, 8.450 / \mathrm{kg}$

Gambar 2. Saluran Pemasaran Di Desa Kuapan

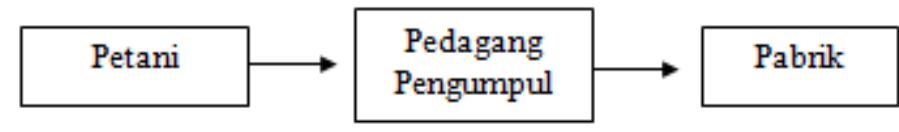

Rp. $6.720 / \mathrm{kg}$

Rp. $8.625 / \mathrm{kg}$

Gambar 3. Saluran Pemasaran di Desa Ridan

Berdasarkan Gambar diatas menunjukkan saluran pemasaran karet yang ada di Kabupaten Kampar yang terdiri dari Desa Sungai Pinang, Kuapan dan Ridan. Saluran pemasaran di Kabupaten Kampar terdapat satu saluran pemasaran yaitu petani karet menjual hasil produksinya ke pedagang pengumpul kemudian pedagang pengumpul menjual karetnya ke pabrik karet.

Tabel 1. Persentase saluran pemasaran

\begin{tabular}{clcccc}
\hline No & Desa & $\begin{array}{c}\text { Jumlah } \\
\text { (orang) }\end{array}$ & Persentase $(\%)$ & $\begin{array}{c}\text { Volume karet dipasarkan } \\
(\text { Kg/Minggu })\end{array}$ & $\begin{array}{c}\text { Persentase } \\
(\%)\end{array}$ \\
\hline 1 & Sungai Pinang & 25 & 33,3 & 2.830 & 32,79 \\
2 & Kuapan & 25 & 33,3 & 2.791 & 32,34 \\
3 & Ridan & 25 & 33,3 & 3.010 & 34,87 \\
\hline & Jumlah & 75 & 100,00 & 8.631 & 100,00 \\
\hline
\end{tabular}

Dari hasil penelitian jumlah petani yang ada di Desa Sungai Pinang berjumlah 25 orang $(33,3 \%)$ dengan volume karet yang dipasarkan $2.830 / \mathrm{kg} /$ minggu, sedangkan jumlah petani yang ada di Desa Kuapan berjumlah $25(33,3 \%)$ dengan volume karet yang dipasarkan sebanyak 2.791/kg/minggu dan jumlah petani yang ada di Desa Ridan berjumlah 25 orang $(33,3 \%)$ dengan volume karet tertinggi yang dipasarkan sebanyak 3.010/kg/minggu. Dapat disimpulkan bahwa volume karet tertinggi yang dipasarkan terdapat di Desa Ridan.

\section{Saluran Pemasaran Desa Sungai Pinang}

Saluran pemasaran di Desa Sungai Pinang merupakan saluran yang melibatkan petani, pedagang pengumpul dan pabrik dalam memasarkan karet. Petani yang terlibat dalam saluran ini sebanyak 25 orang $(33,3 \%)$. Petani yang menjual hasil produksi karetnya kepada pedagang pengumpul dengan cara pedagang pengumpul menjemput langsung hasil panen karet petani di masing-masing lahan petani. Pada saluran ini pedagang pengumpul yang ada di Desa Sungai Pinang biasanya menjemput hasil panen karet petani ketika petani menghubungi pedagang pengumpul. Setelah pedagang pengumpul menjemput hasil panen karet kemasingmasing lahan petani, pedagang pengumpul menjual karetnya ke pabrik karet. Pedagang pengumpul menjual karet di pabrik Hervenia Kampar Lestari. Dari penjelasan diatas dapat disimpulkan bahwa saluran pemasaran yang terjadi di Desa Sungai Pinang adalah saluran pemasaran tingkat satu (one level channel).

Penentuan harga ditetapkan oleh pedagang pengumpul, penentuan harga yang ditetapkan tidak menentu setiap minggunya atau harganya berubah-ubah. Sistem pembayaran pada petani karet di Desa Sungai Pinang dengan pedagang pengumpul adalah dengan pembayaran tunai. Pembayaran tunai adalah pembayaran yang dilakukan secara langsung oleh pedagang pengumpul kepada petani saat berada di tempat pengumpulan karet yang letaknya tidak jauh dari lahan petani.

Petani menjual karetnya kepada pedagang pengumpul karena antara petani dengan pedagang pengumpul sudah terjalin hubungan baik, hubungan kekerabatan, dan petani mendapatkan pinjaman. Pinjaman akan sangat diperlukan pada musim penghujan, dimana petani tidak bisa memanen karetnya sedangkan kebutuhan pokok harus dipenuhi. Petani yang memiliki hutang akan terikat untuk menjual karetnya kepada pedagang 
pengumpul yang memberikan pinjaman. Apabila petani telah bisa memanen karet maka sebagian hasil panen akan digunakan untuk membayar utang.

\section{Saluran pemasaran Desa Kuapan}

Saluran pemasaran di Desa Kuapan merupakan saluran yang melibatkan petani, pedagang pengumpul dan pabrik dalam memasarkan karet. Petani yang terlibat dalam saluran ini sebanyak 25 orang (33,3\%). Petani yang menjual hasil produksi karetnya kepada pedagang pengumpul dengan cara pedagang pengumpul menjemput langsung hasil panen karet petani di masing-masing lahan petani. Penentuan harga ditentukan langsung oleh pedagang pengumpul, penetapan harga tersebut berdasarkan kualitas dan mutu karet.

Sistem pembayaran pada saluran pemasaran ini adalah dengan pembayaran tunai, pembayaran tunai adalah pembayaran yang dilakukan secara langsung oleh pedagang pengumpul kepada petani saat berada di tempat pengumpulan karet yang letaknya tidak jauh dari lahan petani. Setelah itu pedagang pengumpul langsung menjual karetnya ke pabrik karet. Pedagang pengumpul menjual karet ke pabrik Hervenia Kampar Lestari. Dari penjelasan diatas dapat disimpulkan bahwa saluran pemasaran yang terjadi di Desa Kuapan adalah saluran pemasaran tingkat satu (one level channel).

Petani yang menjual karetnya di pedagang pengumpul karena kapan petani panen serta butuh uang petani bisa langsung menjual karetnya ke pedagang pengumpul, selain itu dari awal petani menjual karetnya ke pedagang tersebut. Selain itu antara petani dan pedagang pengumpul sudah terjalin hubungan baik dan pedagang pengumpul bersedia meminjamkan uang kepada petani.

Ketergantungan petani terhadap pedagang pengumpul karena petani sudah memiliki hutang dalam bentuk uang untuk memenuhi kebutuhan yang mendesak, seperti untuk memenuhi kebutuhan pokok dalam kehidupan sehari-hari, sehingga petani memiliki keterikatan dan harus menjual karet ke pedagang pengumpul tersebut.

\section{Saluran pemasaran Desa Ridan}

Saluran pemasaran di Desa Ridan merupakan saluran yang melibatkan petani, pedagang pengumpul dan pabrik. Petani yang terlibat dalam saluran ini sebanyak 25 orang $(33,3 \%)$. Saluran pemasaran yang terjadi di Desa Ridan adalah saluran pemasaran tingkat satu (one level channel).

Petani yang menjual hasil produksi karetnya kepada pedagang pengumpul dengan cara pedagang pengumpul menjemput langsung hasil panen karet petani di masing-masing lahan petani. Pada saluran ini pedagang pengumpul yang ada di Ridan biasanya menjemput hasil panen karet petani ketikapetani menghubungi pedagang pengumpul. Setelah pedagang pengumpul menjemput hasil panen karet kemasingmasing lahan petani, pedagang pengumpul menjual karetnya ke pabrik karet. Pedagang pengumpul menjual karet tersebut ke pabrik Bangkinang.

Penentuan harga yang ditetapkan tidak menentu setiap minggunya atau harganya berubah-ubah. Sistem pembayaran pada petani karet di Desa Ridan dengan pedagang pengumpul adalah dengan pembayaran tunai. Pembayaran tunai adalah pembayaran yang dilakukan secara langsung oleh pedagang pengumpul kepada petani saat berada di tempat pengumpulan.

Petani menjual karetnya kepada pedagang pengumpul karena petani mendapatkan pinjaman uang saat diperlukan pada musim penghujan, dimana petani tidak bisa memanen karetnya sedangkan kebutuhan pokok harus dipenuhi. Petani yang memiliki hutang akan terikat untuk menjual karetnya kepada pedagang pengumpul yang memberikan pinjaman. Apabila petani telah bisa memanen karet maka sebagian hasil panen akan digunakan untuk membayar hutang.

Dari hasil penelitian dapat disimpulakan bahwa saluran pemasaran yang ada di Kabupaten Kampar terdapat satu saluran pemasaran. Saluran pemasaran tersebut melibatkan petani menjual hasil produksi karetnya kepedagang pengumpul, dan kemudian pedagang pengumpul menjual ke pabrik. Pedagang pengumpul menjual karet ke pabrik Hervenia Kampar Lestari dan pabrik Bangkinang.

Penentuan harga ditetapkan oleh pedagang pengumpul, penentuan harga yang ditetapkan tidak menentu setiap minggunya atau harganya berubah-ubah. Penentuan harga ditetapkan berdasarkan mutu dan kualitas yang dihasilkan oleh petani. Selain itu pedagang pengumpul juga melihat kadar air yang dihasilkan oleh karet petani, apabila kadar airnya tinggi maka penyusutan yang diterima petani juga tinggi. Sistem pembayaran pada petani karet di Kabupaten Kampar dengan pedagang pengumpul adalah dengan pembayaran tunai. Pembayaran tunai adalah pembayaran yang dilakukan secara langsung oleh pedagang pengumpul kepada petani saat berada di tempat pengumpulan karet yang letaknya tidak jauh dari lahan petani. 
Keberadaan pedagang pengumpul dalam pemasaran karet sangat diperlukan oleh petani. Bagi petani, pedagang pengumpul sangat diperlukan karena dengan produksi yang dihasilkan dalam jumlah kecil dan jauhnya jarak antara petani dengan pabrik. Selain itu antara pedagang pengumpul dan petani karet juga telah terbina hubungan baik. Ketergantungan petani begitu besar kepada pedagang pengumpul menyebabkan petani tidak mempunyai posisi tawar yang memadai. Lemahnya posisi tawar petani umumnya disebabkan petani kurang mendapatkan atau memiliki akses pasar,informasi pasar dan permodalan yang kurang memadai.Pinjaman uang atau kebutuhan lainnya yang sering dilakukan petani akan membuat petani menjadi terikat kepada pedagang pengumpul tersebut.

\section{Analisis Pemasaran (Biaya, Margin, Keuntungan, farmer share dan Efisiensi)}

Analisis biaya pemasaran menurut fungsi distribusi adalah suatu kegiatan pemasaran yang memerlukan pengeluaran biaya. Analisis biaya pemasaran menurut fungsi ini bertujuan untuk pengendalian biaya dan berguna untuk analisis biaya pemasaran menurut cara penerapan usaha pemasaran. Biaya pemasaran karet ditanggung oleh masing-masing lembaga pemasaran. Analisis pemasaran meliputi biaya pemasaran, margin, keuntungan, farmer share dan efisiensi pemasaran.

\section{Analisis Pemasaran Desa Sungai Pinang}

Pada analisis pemasaran di Desa Sungai Pinang petani menjual karetnya kepada pedagang pengumpul kemudian pedagang pengumpul menjual karetnya ke Pabrik Hervenia Kampar Lestari. Pada saluran pemasaran petani menjual ke pedagang pengumpul dengan harga $\mathrm{Rp} 6.864 / \mathrm{kg}$, harga tersebut ditentukan oleh pedagang pengumpul sesuai dengan kualitas dan mutu karet petani. Pedagang pengumpul akan mengambil karet petani ditempat petani mengumpulkan hasil karetnya, maka petani harus mengeluarkan biaya lansir sebesar Rp100/kg. Petani juga dikenakan biaya penyusutan atau potongan sebesar 10\% dari berat total penjualan yaitu Rp686,4/kg, penyusutan tersebut dikarenakan tingginya kadar air yang dihasilkan oleh petani. Potongan tersebut ditentukan oleh pedagang itu sendiri sesuai dengan kualitas karet. Total biaya pemasaran yang dikeluarkan oleh petani yaitu sebesar Rp786,4/kg. Sistem pembayaran dilakukan secara langsung dengan cara tunai. Untuk melihat analisis pemasaran di Desa Sungai Pinang dapat dilihat Tabel 2.

Tabel 2. Analisis Pemasaran Karet di Desa Sungai Pinang

\begin{tabular}{clrr}
\hline No & \multicolumn{1}{c}{ Uraian } & Jumlah $(\mathrm{Rp} / \mathrm{Kg})$ & \\
\hline 1 & Petani & 6.864 & \\
& Harga Jual $(\mathrm{Rp} / \mathrm{Kg})$ & 786,4 & \\
& Biaya Pemasaran & 100 & \\
& 1. Lansir & 686,4 & \\
& 2. Penyusutan $10 \%$ & 6.864 & \\
2 & Pedagang Pengumpul & 8.45 & \\
& 1. Harga Beli (Rp/Kg) & 1.586 & \\
& 2. Harga Jual (Rp/Kg) & 806 & \\
& Margin Pemasaran & 50 & \\
& Biaya Pemasaran & 80 & \\
& 1. Biaya bongkar/muat & 676 & \\
& 2. Biaya Transportasi & 780 & \\
& 3. Penyusutan 8\% & & \\
& Keuntungan Pemasaran & 8.450 & \\
3 & Pabrik & 1.592 & \\
& Harga Beli & 1.586 & \\
5 & Total Biaya Pemasaran & & \\
6 & Total Marjin Pemasaran & & \\
7 & Farmer share & & \\
\hline
\end{tabular}

Margin pemasaran merupakan perbedaan harga ditingkat petani atau produsen dengan harga di tingkat konsumen akhir. Perbedaan harga tersebut dikarenakan adanya biaya pemasaran dan keuntungan masingmasing lembaga pemasaran yang terlibat dalam saluran tersebut. Pada penelitian ini pemasaran karet diakhiri di konsumen akhir yaitu pabrik, sehingga margin dihitung dari harga yang diterima petani produsen 
dikurangi harga konsumen akhir yang diteliti. Pada penelitian ini diperoleh margin pemasaran di Desa Sungai Pinang adalah Rp1.586/kg yang didapat dari selisih harga yang diterima petani dengan harga yang dibayar oleh pabrik.

Biaya pemasaran yang dikeluarkan oleh pedagang pengumpul yaitubiaya bongkar/muat sebesar $\mathrm{Rp} 50 / \mathrm{kg}$, biaya transportasi sebesar Rp80/kg dan biaya penyusutan sebesar $8 \%$ yaitu Rp676/kg. Total biaya pemasaran pedagang pengumpul yaitu Rp806/kg.

Keuntungan pemasaran menurut Soekartawi (2002), merupakan selisih antara margin pemasaran dengan biaya pemasaran. Keuntungan pemasaran yang diperoleh dari pedagang pengumpul adalah sebesar $\mathrm{Rp} 780 / \mathrm{kg}$.

Farmer Share atau bagian yang diterima petani merupakan harga yang dibayarkan konsumen akhir terhadap petani dalam bentuk persentase. Hasil penelitian menunjukan besarnya bagian yang diterima petani di Desa Sungai Pinang yaitu sebesar sebesar $81,23 \%$. Semakin tinggi farmer share semakin tinggi pula bagian harga yang diterima petani.

Nilai efisiensi pemasaran di Desa Sungai Pinang yaitu sebesar 18,84\%. Semakin kecil nilai efisiensi maka pemasaran yang dilakukan semakin efisien, begitu juga sebaliknya semakin besar nilai efisiensi maka pemasaran semakin tidak efisien (Soekartawi, 2002). Efisiensi pemasaran dapat diperbaiki dengan cara meningkatkan output pemasaran atau dengan mengurangi biaya pemasaran yang dilakukan.

\section{Analisis Pemasaran Desa Kuapan}

Pemasaran karet di Desa Kuapan yaitu petani menjual karetnya kepada pedagang pengumpul kemudian pedagang pengumpul menjual ke pabrik Hervenia Kampar Lestari. Petani menjual karet ke pedagang pengumpul dengan harga $\mathrm{Rp} 6.756 / \mathrm{kg}$, harga tersebut ditentukan langsung oleh pedagang pengumpul sesuai dengan kualitas dan mutu karet petani. Pedagang pengumpul akan mengambil karet petani ditempat petani mengumpulkan hasil karetnya sehingga petani harus mengeluarkan biaya pemasaran. Untuk lebih jelas analisis pemasaran di Desa Kuapan dapat diuraikan pada Tabel 3.

Tabel 3. Analisis Pemasaran Karet di Desa Kuapan

\begin{tabular}{|c|c|c|c|}
\hline No & Uraian & Jumlah $(\mathrm{Rp} / \mathrm{Kg})$ & Persentase $(\%)$ \\
\hline \multirow[t]{5}{*}{1} & Petani & & \\
\hline & Harga Jual (Rp/Kg) & 6.756 & \\
\hline & Biaya Pemasaran & 775,6 & \\
\hline & 1. Lansir & 100 & \\
\hline & 2. Penyusutan $10 \%$ & 675,6 & \\
\hline \multirow[t]{9}{*}{2} & Pedagang Pengumpul & & \\
\hline & 1. Harga Beli $(\mathrm{Rp} / \mathrm{Kg})$ & 6.756 & \\
\hline & 2. Harga Jual $(\mathrm{Rp} / \mathrm{Kg})$ & 8.45 & \\
\hline & Margin Pemasaran & 1.694 & \\
\hline & Biaya Pemasaran & 826 & \\
\hline & 1. Biaya bongkar/muat & 100 & \\
\hline & 2. Biaya Transportasi & 50 & \\
\hline & 3. Penyusutan $8 \%$ & 676 & \\
\hline & Keuntungan Pemasaran & 868 & \\
\hline \multirow[t]{2}{*}{3} & Pabrik & & \\
\hline & Harga Beli & 8.450 & \\
\hline 4 & Total Biaya Pemasaran & $1.601,6$ & \\
\hline 5 & Total Marjin Pemasaran & 1.694 & \\
\hline 6 & farmer share & & 79,95 \\
\hline 7 & Efisiensi Pemasaran & & 18,95 \\
\hline
\end{tabular}

Tabel 3 menunjukkan biaya pemasaran yang dikeluarkan oleh petani yaitu biaya lansir sebesar Rp100/kg dan penyusutan $10 \%$ dari berat total penjualan sebesar Rp675,6/kg, potongan penyusutan dilakukan oleh pedagang pengumpul sesuai dengan kadar air yang dihasilkan oleh petani, total biaya pemasaran yang dikeluarkan oleh petani yaitu Rp775,6/kg. Sistem pembayaran yang dilakukan yaitu secara langsung atau tunai. 
Marjin pemasaran adalah selisih harga yang dibayar konsumen akhir dengan harga yang diterima petani (Sudiyono, 2001), sehingga margin yang diperoleh pedagang pengumpul sebesar Rp1.694/kg yang didapat dari selisih harga yang diterima petani dengan harga yang dibayar oleh pedagang pengumpul. Keuntungan pemasaran yang diperoleh dari pedagang pengumpul yaitu Rp868/kg. Keuntungan tersebut diperoleh dari margin yang diterima pedagang pengumpul dengan biaya yang dikeluarkan. Sistem pembayaran yang dilakukan pabrikyaitu secara langsung atau tunai.

Farmer share atau bagian yang diterima petani merupakan harga yang dibayarkan konsumen akhir terhadap petani dalam bentuk persentase. Bila bagian yang diterima petani kurang dari $50 \%$ berarti belum efisien, dan bila bagian yang diterima petani lebih dari 50\% maka pemasaran dikatakan efisien. Hasil penelitian menunjukan besarnya bagian yang diterima petani di Desa Kuapan sebesar 79,95 \%.Dibandingkan dengan pemasaran di Desa Sungai Pinang bagian yang di terima petanilebih efisien dikarenakan besarnya jumlah bagian yang diteima oleh petaniyaitu sebesar $81,23 \%$, hal ini disebabkan oleh tingginya harga yang diterima ditingkat petani pada Desa Sungai Pinang. Semakin tinggi farmer share semakin tinggi pula bagian harga yang diterima petani.

Nilai efisiensi pemasaran karet di Desa Kuapan yaitu sebesar 18,95\%. Semakin kecil nilai efisiensi maka pemasaran yang dilakukan semakin efisien, begitu juga sebaliknya semakin besar nilai efisiensi maka pemasaran semakin tidak efisien (Soekartawi, 2002). Hasil penelitian menunjukkan bahwa efisiensi pemasaran di Desa Sungai Pinang lebih kecil yaitu 18,84 \% dibandingkan dengan Desa Kuapan. Hal ini menunjukan bahwa nilai efisiensi pemasaran di Desa Sungai Pinang lebih efisien dari pada pemasaran di Desa Kuapan, hal ini terjadi dikarenakan kecilnya total biaya yang dikeluarkan pada saluran pemasaran di Desa Sungai Pinang. Efisiensi pemasaran juga dapat dilihat dari panjang-pendeknya saluran pemasaran yang dilakukan dalam proses pemasaran. Semakin panjang saluran pemasaran yang dilewati maka semakin banyak lembaga pemasaran yang terlibat, maka semakin tidak efisien pemasaran tersebut.

\section{Analisis Pemasaran Desa Ridan}

Pada analisis pemasaran di Desa Ridan petani menjual karetnya kepada pedagang pengumpul kemudian pedagang pengumpul menjual karetnya ke Pabrik Bangkinang. Pada saluran pemasaran petani menjual ke pedagang pengumpul dengan harga $\mathrm{Rp} 6.720 / \mathrm{kg}$, harga tersebut ditentukan oleh pedagang pengumpul.Pedagang pengumpul akan mengambil karet petani ditempat petani mengumpulkan hasil karetnya, maka petani harus mengeluarkan biaya lansir sebesar Rp200/kg. Petani juga dikenakan biaya penyusutan atau potongan sebesar $10 \%$ dari berat total penjualan yaitu Rp.672/kg. Potongan tersebut ditentukan oleh pedagang itu sendiri sesuai dengan kualitas karet dan kadar air yang dihasilkan oleh petani. Total biaya pemasaran yang dikeluarkan oleh petani yaitu sebesar Rp872/kg. Sistem pembayaran dilakukan secara langsung dengan cara tunai. Untuk melihat analisis pemasaran di Desa Ridan dapat dilihat Tabel 4.

Tabel 4. Analisis Pemasaran Karet di Desa Ridan

\begin{tabular}{|c|c|c|c|}
\hline No & Uraian & Jumlah (Rp/Kg) & Persentase $(\%)$ \\
\hline \multirow[t]{5}{*}{1} & Petani & & \\
\hline & Harga Jual (Rp/Kg) & 6.72 & \\
\hline & Biaya Pemasaran & 872 & \\
\hline & 1. Lansir & 200 & \\
\hline & 2. Penyusutan $10 \%$ & 672 & \\
\hline \multirow[t]{9}{*}{2} & Pedagang Pengumpul & & \\
\hline & 1. Harga Beli (Rp/Kg) & 6.72 & \\
\hline & 2. Harga Jual (Rp/Kg) & 8.625 & \\
\hline & Margin Pemasaran & 1.905 & \\
\hline & Biaya Pemasaran & 867,5 & \\
\hline & 1. Biaya bongkar/muat & 200 & \\
\hline & 2. Biaya Transportasi & 150 & \\
\hline & 3. Penyusutan $6 \%$ & 517,5 & \\
\hline & Keuntungan Pemasaran & $1.037,5$ & \\
\hline \multirow[t]{2}{*}{3} & Pabrik & & \\
\hline & Harga Beli & 8.625 & \\
\hline 4 & Total Biaya Pemasaran & $1.739,5$ & \\
\hline 5 & Total Marjin Pemasaran & 1.905 & \\
\hline
\end{tabular}




\begin{tabular}{|c|c|c|c|}
\hline No & Uraian & Jumlah (Rp/Kg) & Persentase $(\%)$ \\
\hline 6 & farmer share & & 77,91 \\
\hline 7 & Efisiensi Pemasaran & & 20,19 \\
\hline
\end{tabular}

Margin pemasaran merupakan perbedaan harga ditingkat petani atau produsen dengan harga di tingkat konsumen akhir. Perbedaan harga tersebut dikarenakan adanya biaya pemasaran dan keuntungan masingmasing lembaga pemasaran yang terlibat dalam saluran tersebut. Pada penelitian ini pemasaran karet diakhiri di konsumen akhir yaitu pabrik, sehingga margin dihitung dari harga yang diterima petani produsen dikurangi harga konsumen akhir yang diteliti. Pada penelitian ini diperoleh margin pemasaran di Desa Ridan Permai adalah Rp1.905/kg yang didapat dari selisih harga yang diterima petani dengan harga yang dibayar oleh pabrik.

Biaya pemasaran yang dikeluarkan oleh pedagang pengumpul yaitu biaya bongkar/ muat sebesar Rp.200/kg, biaya transportasi sebesar Rp150/kg dan biaya penyusutan sebesar $6 \%$ yaitu Rp.517,5/kg. Total biaya pemasaran pedagang pengumpul yaitu Rp.867,5/kg.Keuntungan pemasaran menurut Soekartawi (2002), merupakan selisih antara margin pemasaran dengan biaya pemasaran. Keuntungan pemasaran yang diperoleh dari pedagang pengumpul adalah sebesar Rp1.037,5/kg.

Farmer Share atau bagian yang diterima petani merupakan harga yang dibayarkan konsumen akhir terhadap petani dalam bentuk persentase. Hasil penelitian menunjukan besarnya bagian yang diterima petani di Desa Ridan yaitu sebesar 77,91\%. Dapat disimpulkan bahwa farmer share yang ada di Desa Ridan kecil bagian harga yang diterima oleh petani dibandingkan dengan Desa Sungai Pinang dan Kuapan.

Nilai efisiensi pemasaran di Desa Ridan yaitu sebesar 20,19\%. Di bandingkan dengan Desa Sungai Pinang dan Kuapan nilai efisiensi pemasarannya kecil, hal ini berarti semakin kecil nilai efisiensi maka pemasaran yang dilakukan semakin efisien, begitu juga sebaliknya semakin besar nilai efisiensi maka pemasaran semakin tidak efisien (Soekartawi, 2002). Hal ini terjadi dikarenakan kecilnya biaya pemasaran di Desa Sungai Pinang dan Desa Kuapan. Efisiensi pemasaran dapat diperbaiki dengan cara meningkatkan output pemasaran atau dengan mengurangi biaya pemasaran yang dilakukan.

Hasil penelitian menunjukan bahwa analisis pemasaran di Kabupaten Kampar menunjukkan bahwa biaya pemasaran yang di keluarkan oleh petani yaitu biaya lansir dan penyusutan. Biaya lansir ditentukan oleh pedagang pengumpul sesuai dengan jarak tempuh yang dilakukan oleh pedagang pengumpul ke lahan petani. Tingginya biaya penyusutan karet selama proses pemasaran disebabkan oleh tingginya kandungan air pada karet yang dihasilkan oleh petani. Potongan penyusutan oleh pedagang pengumpul kepada petani yaitu sebesar $10 \%$. Hal ini terjadi dikarena tingginya kadar air yang dihasilkan petani di Desa Sungai Pinang, Kuapan dan Ridan.

Harga karet yang di terima oleh petani mengikuti ketetapan harga yang ditetntukan oleh pedagang pengumpul. Dalam menentukan harga pedagang pengumpul menentukan kualitas karet yang dijual oleh petani sehingga pedagang pengumpul memiliki wewenang penuh melakukan pemotongan harga berdasarkan kualitas yang ditetapkan tersebut.

Pada umumnya petani karet di Kabupaten Kampar tidak mengetahui informasi harga karet yang terjadi sebenarnya di pabrik dan hanya menerima harga yang diberikan oleh pedagang pengumpul. Lemahnya posisi tawar petani umumnya disebabkan petani kurang mendapatkan atau memiliki akses pasar.Petani tidak tahu informasi pasar tentang harga karet dan tidak tahu seberapa besar kenaikan atau penurunan harga karet yang sedang terjadi di pabrik, karena petani tidak mempunyai akses untuk memasuki pabrik. Dari pihak pedagang, justru memanfaatkan kondisi ini untuk menekan harga jual demi mendapatkan keuntungan yang besar. Selain itu kemampuan petani dalam penawaran karet yang dihasilkan masih terbatas karena keterbatasan modal yang dimiliki, sehingga ada kecenderungan karet yang dihasilkan dijual dengan harga yang rendah. Berdasarkan keadaan tersebut, maka yang meraih keuntungan besar pada umumnya adalah pihak pedagang.

Petani berusaha untuk tetap menjaga kualitas karetnya supaya harga yang di terima oleh petani tinggi dan pedagang merasa senang untuk membeli karet tersebut. Ciri-ciri kualitas karet yang baik yaitu bersih, tidak terdapat tatal dan memiliki kadar air yang rendah. Apabila kualitas karet petani rendah pedagang tetap mau membeli karet tersebut dengan harga yang sangat rendah. Petani yang memiliki kualitas karet yang rendah dengan ciri-ciri banyak terdapat kayu atau tatal, sampah-sampah daun dan kadar air yang tinggi. Sebelum karet di timbang dan diangkat ke mobil biasanya pedagang pengumpul memeriksa karetnya terlebih dahulu baru dilakukan penimbangan. 
Hasil penelitian menunjukan besarnya Farmer share atau bagian yang diterima petani di Kabupaten Kampar yang lebih efisien di Desa Sungai Pinang dibandingkan dengan Desa Kuapan dan Ridan dikarenakan besarnya jumlah bagian yang diterima oleh petani yaitu sebesar $81,23 \%$. Semakin tinggi farmer share semakin tinggi pula bagian harga yang diterima petani. Hal ini terjadi dikarenakan tingginya harga yang diterima petani karena kualitas yang dihasilkan petani cukup baik di Desa Sungai Pinang dibandingkan dengan harga dan kualitas karet yang diterima oleh petani di Desa Kuapan dan Ridan.

Apabila dilihat dari efisiensi pemasarannya di Desa Sungai Pinang lebih kecil yaitu 18,84\% dibandingkan dengan Desa Kuapan dan Ridan. Hal ini menunjukkan bahwa nilai efisiensi pemasaran di Desa Sungai Pinang lebih efisien dari pada pemasaran di Desa Kuapan dan Ridan. Hal ini terjadi karena kecilnya biaya pemasaran yang terjadi di Desa Sungai Pinang. Semakin kecil nilai efisiensi maka pemasaran yang dilakukan semakin efisien, begitu juga sebaliknya semakin besar nilai efisiensi maka pemasaran semakin tidak efisien (Soekartawi, 2002). Efisiensi pemasaran dapat diperbaiki dengan cara meningkatkan output pemasaran atau dengan mengurangi biaya pemasaran yang dilakukan.

\section{KESIMPULAN}

1. Saluran pemasaran paling efisien berdasarkan nilai marjin pemasaran, farmer's share dan tingkat keuntungan (profitability index) yang diperoleh terdapat pada saluran pemasaran III yaitu di Desa Ridan, dengan nilai keuntungan pemasaran sebesar Rp. 1.037,5, margin pemasaran sebesar Rp.1.905 dan nilai farmer's share sebesar 77,91\% dengan efisiensi pemasaran $20,19 \%$.

2. Farmer share atau bagian yang diterima petani di Kabupaten Kampar yang lebih efisien di Desa Sungai Pinang dibandingkan dengan Desa Kuapan dan Ridan dikarenakan besarnya jumlah bagian yang diterima oleh petani yaitu sebesar $81,23 \%$. Semakin tinggi farmer share semakin tinggi pula bagian harga yang diterima petani. Hal ini terjadi dikarenakan tingginya harga yang diterima petani karena kualitas yang dihasilkan petani cukup baik di Desa Sungai Pinang dibandingkan dengan harga dan kualitas karet yang diterima oleh petani di Desa Kuapan dan Ridan.

3. Biaya pemasaran yang di keluarkan oleh petani yaitu biaya lansir dan penyusutan. Biaya lansir ditentukan oleh pedagang pengumpul sesuai dengan jarak tempuh yang dilakukan oleh pedagang pengumpul ke lahan petani. Tingginya biaya penyusutan karet selama proses pemasaran disebabkan oleh tingginya kandungan air pada karet yang dihasilkan oleh petani. Potongan penyusutan oleh pedagang pengumpul kepada petani yaitu sebesar $10 \%$. Hal ini terjadi dikarena tingginya kadar air yang dihasilkan petani di lokasi penelitian.

\section{UCAPAN TERIMA KASIH}

Terima kasih kepada Pimpinan di Universitas Riau serta seluruh jajarannya, atas bantuannya sehingga kegiatan penelitian ini terlaksana sesuai harapan.

\section{DAFTAR PUSTAKA}

Azzaino, Z. 1991. Pengantar Pemasaran Pertanian. Departemen Ilmu-ilmu Sosial Ekonomi Institut Pertanian Bogor. Bogor.

BPS Kabupaten Kampar. 2017. Kabupaten Kampar. Riau

Downey, W., dan Erickson. 1989. Manajemen Agribisnis (terjemahan Ir. Rochidayat Ganda S dan Alfonsus Sirait), Edisi Kedua. Jakarta: Erlangga.

Gitosudarmo, I. 1994. Manajemen Pemasaran. Yogyakarta: BPFE-Yogyakarta.

Kotler, P., dan G. Armstrong. 2001. Prinsip-prinsip Pemasaran Edisi Kedelapan Jilid I. Jakarta: Erlangga.

Maulidi, Sitorus, dan Mahdi, 1992. Analisa Pemasaran Jahe Gajah di Daerah Sentra Produksi Sumatera Utara. Bogor: Balai penelitian Tanaman Rempah dan Obat.

Mubyarto. 1985. Pengantar Ekonomi Pertanian. Jakarta: Lembaga Pertanian, Pendidikan dan Penerangan Sosial Ekonomi (LP3ES).

Soekartawi. 1993. Prinsip Dasar Ekonomi Pertanian. Teori dan Aplikasinya. Bogor: Raja Grafindo Persada.

Soekartawi. 2002. Prinsip Ekonomi Pertanian. Jakarta: Rajawali Pers.

Sudiyono. 2001. Statistika Untuk Penelitian. Bandung: Alfabeta. 